\title{
INSPECTION, DIAGNOSIS AND MODELLING OF AZURARA CHURCH IN THE NORTH OF PORTUGAL
}

\author{
ESTEFANÍA A. CHAVES MORENO ${ }^{1 *}$, ELLEN T. KEY ${ }^{1}$, AMRUTA UPLEKAR ${ }^{1}$, \\ OMAR PINO ACUÑA ${ }^{1}$, GRAÇA VASCONCELOS ${ }^{1}$, JAVIER ORTEGA ${ }^{1}$, ELISA \\ POLETTI $^{1}$ \\ ${ }^{1}$ University of Minho \\ Campus of Azurém, 4800-058, Guimarães, Portugal \\ e-mail: echaves@us.es, ellenkey@ucla.edu, amrutauplekar@gmail.com,opino31@gmail.com, \\ graca@civil.uminho.pt, javier.ortega@civil.uminho.pt, elisapoletti@gmail.com (*corresponding \\ author)
}

Keywords: Masonry, Non-Destructive Tests, Finite Element Modelling

\begin{abstract}
Santa Maria de Azurara church is a XVI century church in Portugal, classified as a national monument since 1910. The building shows not only the influence of the Manueline architectural style (Portuguese late Gothic style), but also Baroque and Mannerism styles. Presently, the church presents some structural and non-structural problems, so an inspection and diagnosis of the main building pathologies was carried out. This process was assisted by non-destructive testing (NDT) techniques which included sonic tests, ground penetrating radar (GPR) and Schmidt hammer for masonry elements and Pilodyn and ultrasonic pulse velocity for the timber elements. In addition, scanning electron microscope and $x$-ray diffraction analysis were used for mortar and stone characterization. Furthermore, dynamic identification tests were performed. Numerical analysis was performed to assess the nonlinear behaviour of the structure under different load conditions. In order to create an accurate model, material properties were estimated from the non-destructive tests and the dynamic properties were used to calibrate the model. A nonlinear static analysis (pushover) considering both vertical and horizontal loading was carried out in order to obtain the maximum load factor for the structure.
\end{abstract}

\section{INTRODUCTION}

Located in the Azurara parish of northwest Portugal, the church of Santa Maria is a local landmark. It is a masonry church dating to the XVI century near the town of Vila do Conde about $25 \mathrm{~km}$ north of Porto. Between October 2018 and March 2019, in the scope of the Advanced Master of Structural Analysis of Historical Constructions (SAHC), a team from the University of Minho analysed the church with non-destructive testing, monitoring systems and nonlinear structural analysis using the finite element method. This paper summarizes the work performed and the results. 


\section{BACKGROUND INFORMATION ON THE CHURCH}

The construction of this Catholic church began in 1502 but finished with the apse in 1552 , during the reign of King Joao III. For this reason, it could be considered as an example of the Manueline architectural style, a Portuguese style that occurred during the reign of King D. Manuel I between the Gothic and Renaissance styles. During the centuries, several structural changes were made (Figure 1). The church was classified as a national monument in 1910. Interventions in the XX century were made to reduce moisture problems in the floor [1].

The structure of the church is based in massive granite three-leafed walls forming three naves with a timber roof. Octagonal columns and Romanesque arches divide the central and lateral naves. The structural system of the chancel is composed of two stone cross vaults supported in external walls and buttresses. The XVII century tower structure (blue in Figure 1) is composed mainly of very thick external walls. Behind the apse is a small chapel thought to be added in the XVIII century, composed of irregular masonry walls (green in Figure 1).

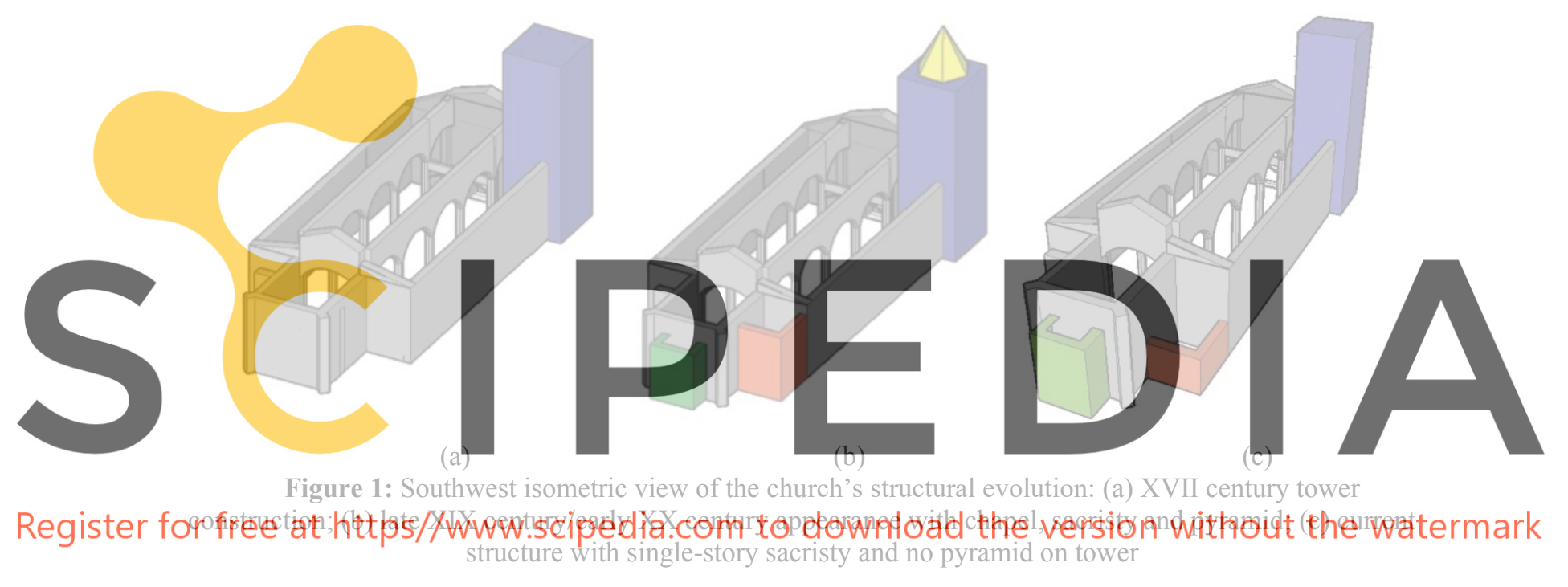

\section{DAMAGE SURVEY}

Inspection of the church led to the creation of damage maps. First, an in situ visual survey was carried out to identify the damages. This was complemented with a photography survey, where pictures of the damages were taken as well as photos for the creation of a photogrammetry model that would provide information about the geometry and the basis for the creation of the damage maps. The most prevalent types of damage are summarized here, according to ICOMOS guidelines [2]. An overall cause of much of the damage was water infiltration.

\subsection{Cracks}

The most prevalent appearance of cracks is on the bell tower. Major cracks can be seen on the exterior part of its western facade, under the balcony projection. Also, a major crack is noted on the internal facade which was measured and marked previously in the year 1985 (Figure 2). The crack meter placed there has detected movement since that date. 


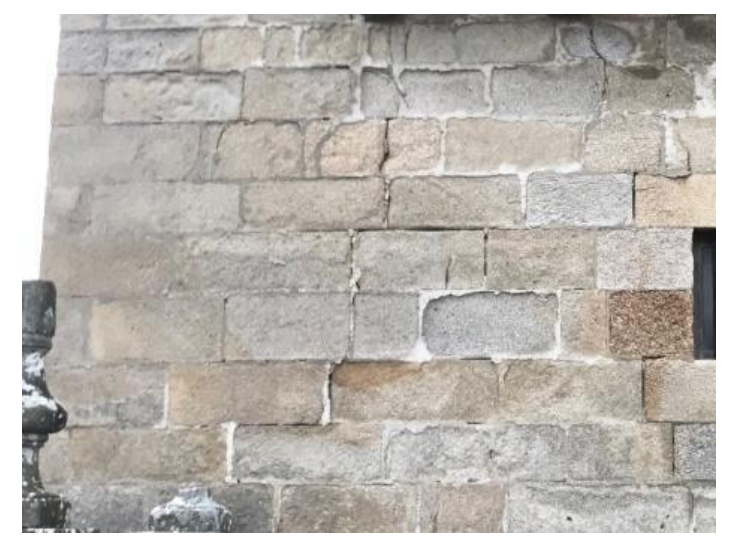

(a)

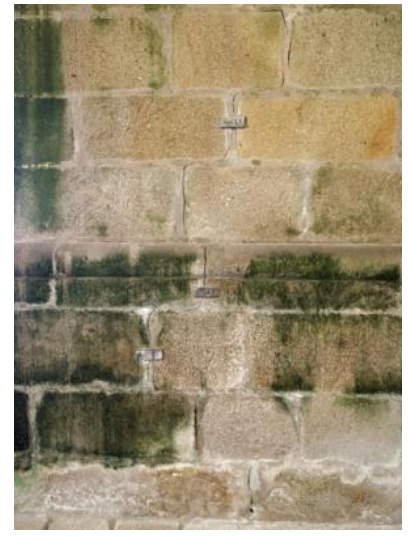

(b)

Figure 2: Cracks under the balcony of the tower in (a) external west facade and (b) internal east facade.

\subsection{Discoloration and deposit}

Staining and soiling were present on the exterior walls. Moist areas could be seen in the interior. Efflorescence was densely observed on the lower areas of the internal surface of the walls (Figure 3(a)). It was also observed in areas close to the roof and all the column bases (Figure 3(b),(c)). Clearly, the existing drainage system is not sufficient. The problems in the rainwater system in the roof are the cause of this pathology in the upper part of the walls.
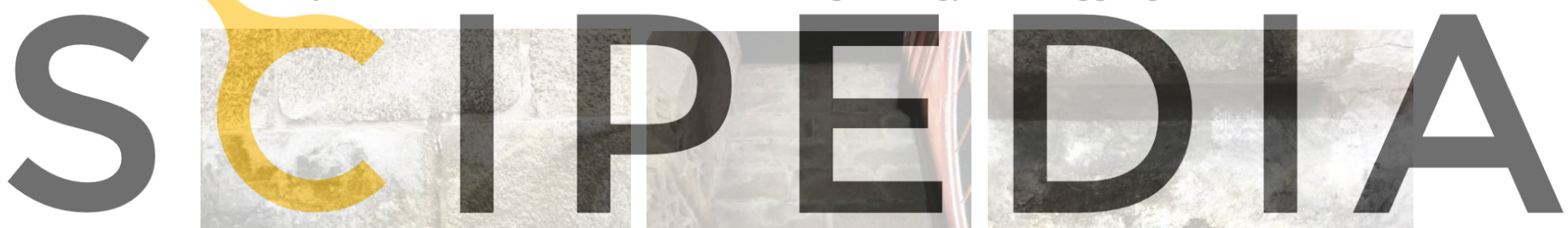

Register for free at https//www.scipedia.com to download

(a)

(b)

(c)

Figure 3: Efflorescence damage observed in (a) internal wall, (b) areas close to the roof and (c) column bases

\subsection{Material loss}

Two main types of material loss, erosion and loss of mortar, were observed. Erosion was mainly seen in external decorative elements and extensively on the western facade of the tower. Loss of mortar was seen on all facades in varying degrees.

\subsection{Biological colonization}

Plants and lichen were observed on the external facades due to inaccessibility, lack of cleanliness and maintenance. Widespread growth of algae can be seen in the interior walls and columns (Figure 4(a),(b)). Algae generally constitute superficial films. However, in the church interior they seem to be growing within the stone rather than on the surface. 
The timber altars and roof are heavily infested with termites, wood boring beetles and rot (Figure 4(c),(d)). Termites have infiltrated all of the altars; the small room behind the main altar is the most infested. Trails can be found throughout the building, including in masonry. Holes created by wood boring beetles can mostly be seen on decorative parts of the altars.

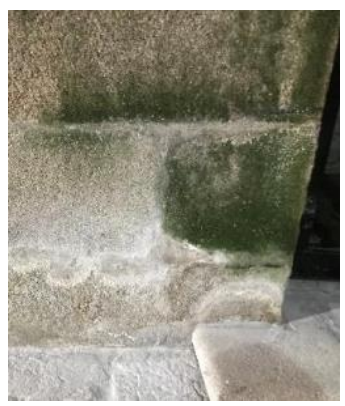

(a)

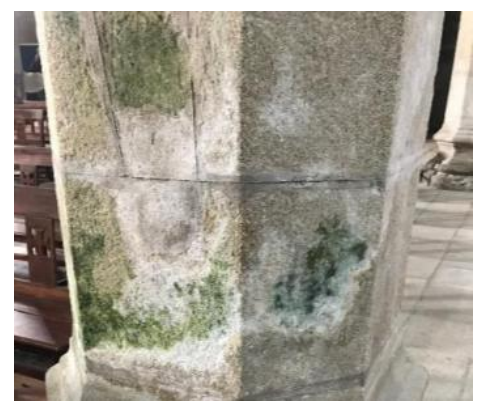

(b)

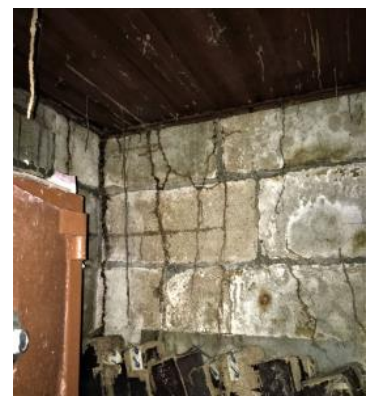

(c)

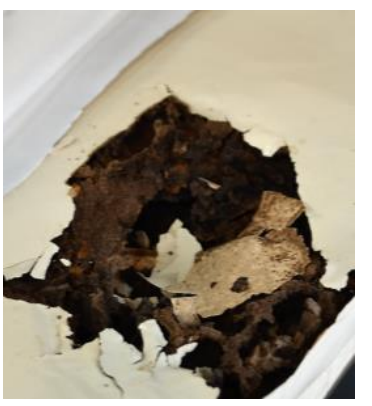

(d)

Figure 4: Algae observed on (a) interior walls and (b) column base; (c) termite infestation behind altar; (d) rot in altar

\section{MONITORING SYSTEM}

Monitoring systems such as crack meters and humidity sensors were installed while thermographic photographs and moisture sensors were used to check the health of the church.

Humidity sensors we

near the interior face of was January to March of the analysed locations and had the greatest flue activity, four crack meters have been placed in ding wall, one on the tower exterior and one in a colum

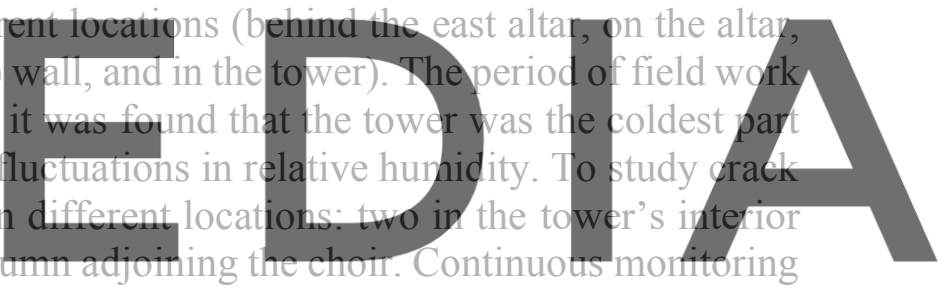
will allow the evaluation of humidity's role in the damage pathologies in the church and the

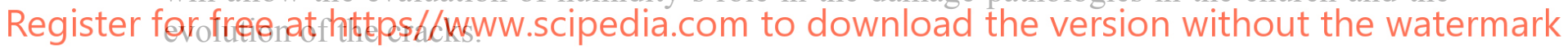

Thermographic images were taken in various locations and helped to identify areas of moisture, voids, and possible insect attack. They are also helpfut in determining if the termites are active or not, but in this case no active termites were found.

A moisture sensor was used to test for moisture at 5,10 , or $30 \mathrm{~cm}$ deep in all the columns and the north and south walls. Upon testing it was observed that the readings from the external facade were similar to the internal ones, so it can be observed that even though the external facade appears dry on the surface, it is moist within. It can be inferred that the south wall has higher moisture content than the north wall, correlating with the higher damage seen (efflorescence and biological colonization). From the distribution observed it is clear that the higher moisture concentrations are in the bottom of the walls. The centre of the floor also has extremely high moisture levels.

\section{NON-DESTRUCTIVE TESTING}

To understand the properties and the behaviour of the church, many tests were performed such as sonic impact tests, rebound hammer, ground penetrating radar as well as some laboratory 
tests where some samples were analysed with scanning electron microscopes and X-ray diffraction.

\subsection{Stone}

Both direct and indirect sonic impact tests were carried out. The masonry in the main body of the church had average Poisson ratio 0.18 and elastic modulus $2.9 \mathrm{GPa}$, which is comparable to a dressed rectangular stone masonry and higher than the values for a cut stone with good bonding per the Italian building code commentary [3]. The irregular masonry of the tower stairwell and the apse saw the lowest values (2.4 and $1.3 \mathrm{GPa}$, respectively). The results for the tower walls indicated a very high elastic modulus, over $4 \mathrm{GPa}$, and Poisson ratio about 0.3.

The rebound hammer test was performed on the face of the stone wall using a Schmidt hammer. Four or five readings were taken at each of five to nine points on each wall. The mean was 40.5 for the main body masonry, 36.2 for the tower and 32.1 for the apse. It can be said that these values are low compared to the literature, possibly due to surficial damages [4].

For ground penetrating radar, the equipment used was the control unit PROEx and an 800 $\mathrm{MHz}$ central frequency antenna from Guideline Geo. In walls, horizontal and vertical profiles were carried out. The scans showed that the main body walls have multi-leaf masonry with a relatively regular inner leaf that has properties similar to those of the outer leaves. In columns, only vertical profiles were performed. The stones within a single drum are well-cut and fitted with a thin joint between them, but between drums the fitting does not seem flat.

To investigate the qor salts were obtained from samples obtained were electron microscope (SE in the south wall, close to the main altar, correspe for the column the salt detected was sodium sulp
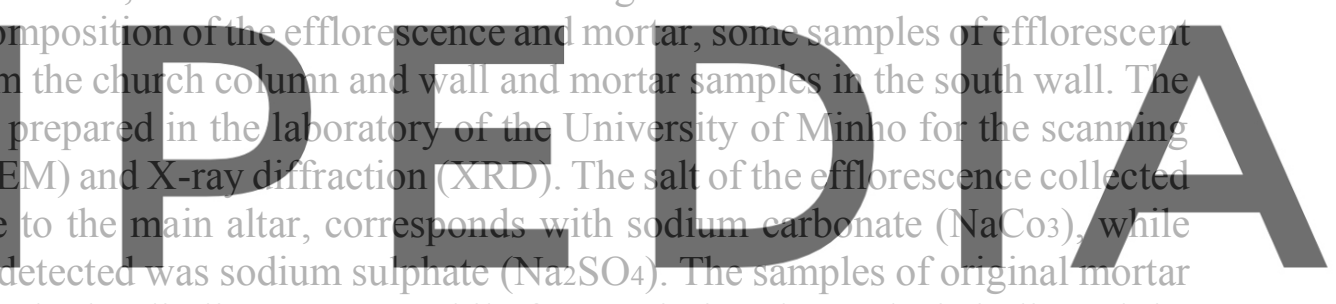
indicated the use of non-hydraulic lime mortar, while for repointing the analysis indicated the

Register forefrefyatahtibpsbruww.scipedia.com to download the version without the watermark

\subsection{Timber}

Pilodyn tests found that there was probably little or no decay in the timber roof beams. Direct ultrasonic tests were also performed on the roof beams. The average velocity measured was consistently in the mid-1900s. This uniformity supports the Pilodyn conclusion that there is little or no decay in these timber elements, since decay would not likely be uniform. The tests were not necessary for the timber altars, in which severe decay was clearly visible.

\section{DYNAMIC IDENTIFICATION TEST}

A representative part of the church was chosen for analysis; namely, the tower and the north walls connected to it. Twelve points of measurement were chosen: five in the bell tower, four in the clerestory wall and three in the external wall (Figure 5). The accelerometers measured the out-of-plane acceleration at every point and in-plane acceleration at one point of each structural element. 


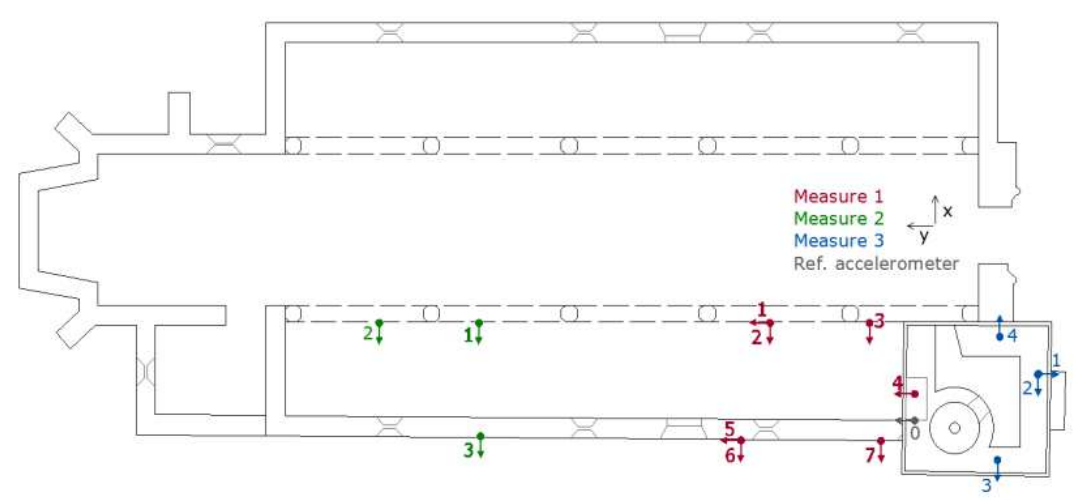

Figure 5: Accelerometer locations for OMA campaign

The information obtained in the campaign was analysed with the program ARTeMIS modal. The software uses two methods of modal identification, and then compares them for validation. Values including damping ratio or complexity of the mode were taken into account as well as the Modal Assurance Criterion values and a visual analysis of the modal shapes; the values are summarised in Table 1. The first four modes were selected for the calibration of the finite element model.

Table 1: Results of the dynamic identification
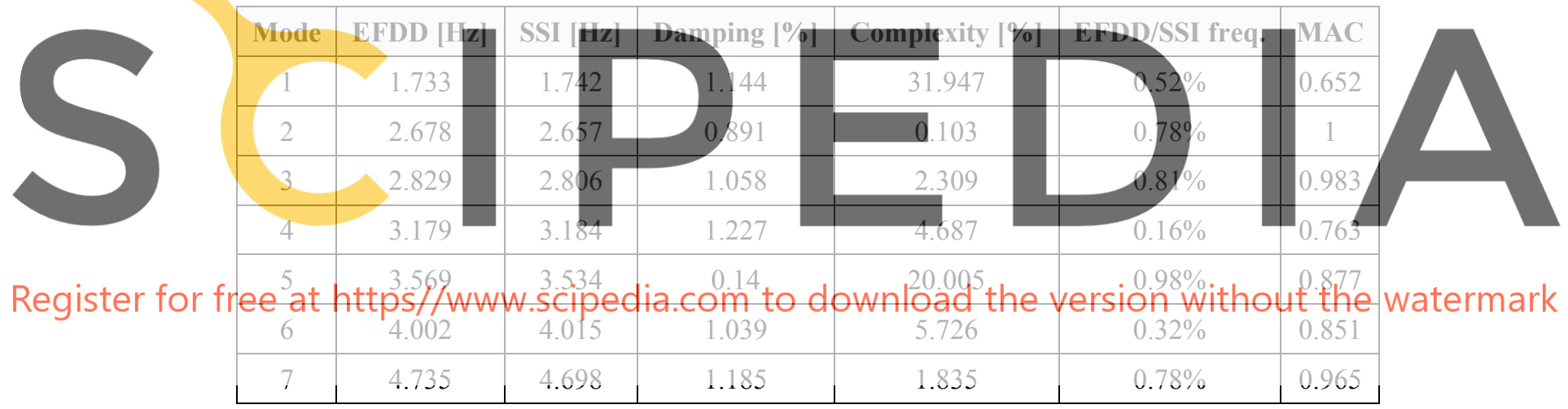

\section{FINITE ELEMENT MODEL}

Finite element analysis was performed with the software Displacement Analyser Finite Element Analysis (DIANA-FEA). Two finite element models were created to analyse the church by importing the AutoCAD models into DIANA-FEA. One was a full shell model (created with 2D elements) created for quicker analyses and one was a solid model (created with primarily $3 \mathrm{D}$ and a few $2 \mathrm{D}$ elements) for improved accuracy.

For the shell model, the surfaces were defined as regular flat shells in DIANA. The columns were defined as wire elements. For the solid model, objects were defined in DIANA as regular solid elements. Both models included a curved shell vault in the chancel and timber rafters for stiffness and behaviour. The vault is considered a thin shell element, so in DIANA it remained a shell element in both the shell and solid models.

The properties chosen were based on the Italian building code and commentary, the nondestructive testing explained herein, and Model Code 2010 [1,5,6]. Nonlinear properties were 
chosen based on several sources in the literature [7,8,9]. Material properties were later modified so that the model matched the dynamic analysis.

Using quadratic mesh order, the mid-side node location was located on shape in order to keep the nodes within the geometry even when the geometry was curved.

Eight-node quadrilateral isoparametric curved shell elements were used for the shell elements (CQ40F). The wire elements were defined as Class-III 3D beam elements, which are curved beam elements with three nodes (CL18B). The solid elements were defined as quadratic/hexagonal mesh elements (primarily the CHX60 twenty-node isoparametric solid brick element) [10].

The roof was not geometrically defined in the model. Rather, the roof structure was considered as a $2 \mathrm{kN} / \mathrm{m} 2$ dead load on the walls and the arcades. Supports were defined as fixed translation in all directions at the base of the walls and columns.

\subsection{Updating of the model}

Once the model was defined, the next step was to use the results from dynamic identification (OMA) to update the model through the comparison of the frequencies and modal shapes.

It was seen in the mode shapes of the dynamic testing campaign that the arcade and the walls were moving together. Therefore, connections between these elements were created. Another facet of the model that was adjusted was the flexibility (elastic modulus) in the connection between the tower's external walls and the west and north facades.

\section{The structural role}

modelling, it was deter

frequency between the

connection of the slab wit

The elastic modulus
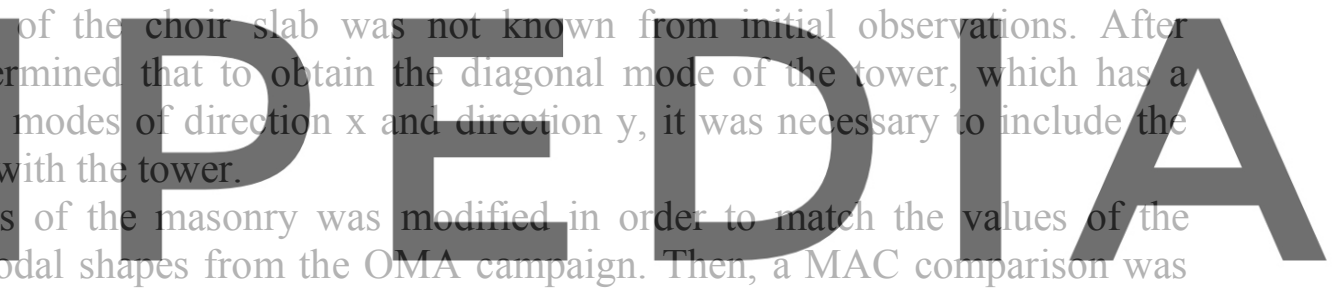

also used. The final properties are listed in Table 2 and the four selected mode shapes are

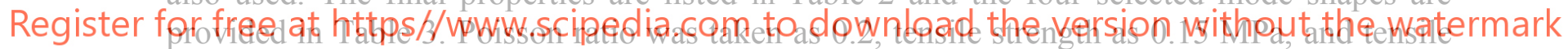
fracture energy $8 \mathrm{~N} / \mathrm{m}$.

Table 2: Material properties assigned in the finite element model

\begin{tabular}{|l|c|c|c|c|c|}
\hline Material type & \multicolumn{3}{|c|}{ Masonry } & Concrete & Timber \\
\hline Structural components & $\begin{array}{c}\text { Walls of the main } \\
\text { nave, arcade, } \\
\text { columns, vault }\end{array}$ & $\begin{array}{c}\text { Tower external } \\
\text { walls, masonry } \\
\text { tower floor }\end{array}$ & $\begin{array}{c}\text { Walls of } \\
\text { apse, tower } \\
\text { stairwell }\end{array}$ & $\begin{array}{c}\text { Concrete } \\
\text { tower } \\
\text { floors }\end{array}$ & $\begin{array}{c}\text { Beams } \\
\text { and ties }\end{array}$ \\
\hline Elastic modulus (GPa) & 1.75 & 1.4 & 1 & 30 & 0.7 \\
\hline Mass density (kg/m) & 2143 & 2041 & 1939 & 2500 & 700 \\
\hline Compressive strength (MPa) & 2.6 & 1.8 & 1.0 & - & - \\
\hline $\begin{array}{l}\text { Compressive fracture energy } \\
\text { (N/mm) }\end{array}$ & 4.16 & 2.88 & 1.60 & - & - \\
\hline
\end{tabular}


Table 3: Modal shapes and frequencies of the OMA (ARTeMIS) results and updated FEM

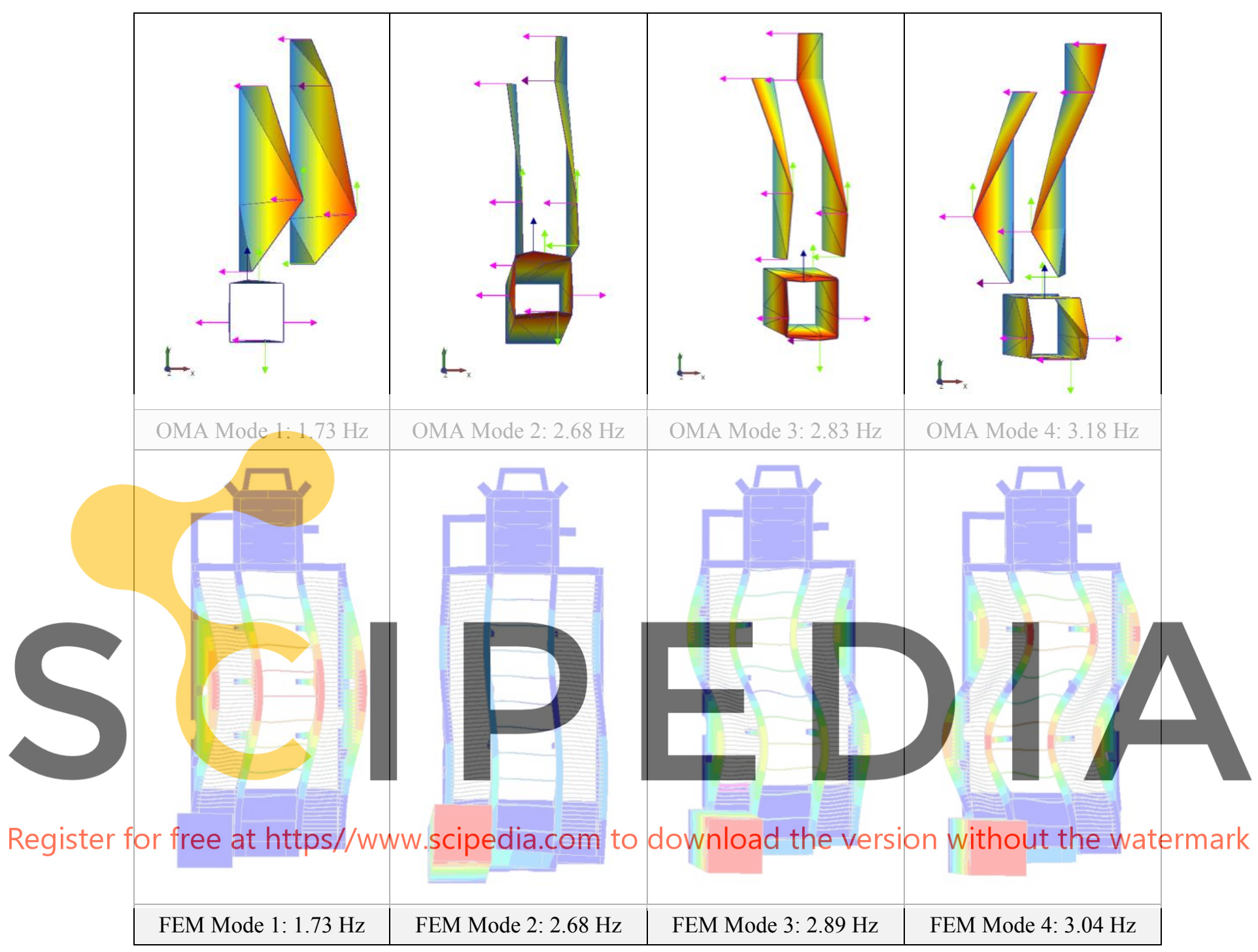

\section{STRUCTURAL ANALYSIS}

Nonlinear analysis was performed with a pushover analysis of the 3D solid model in the vertical and horizontal directions.

The first analysis was performed in the vertical direction in order to obtain the maximum load factor for the gravitational load that the structure can support. The capacity curve is shown in Figure 6. Different models were created with different values for the variables that define the nonlinear analysis. Three values for the tensile fracture energy were used, 8,50 and $1000 \mathrm{~N} / \mathrm{m}$. A model without the slab of the choir was also analysed. Model 1 represents the original model whose material properties are defined in the previous section. For Model 2 the slab was removed. Model 3 and Model 4 present higher tensile fracture energy, $50 \mathrm{~N} / \mathrm{m}$ and $1000 \mathrm{~N} / \mathrm{m}$ respectively. The results are similar for all the cases, reaching a maximum value for the load factor of 2.3 for the original model. It can be observed that for the current state of loading, the 
structure is in the linear range what means that no problems should appear in the structure related to the materials.

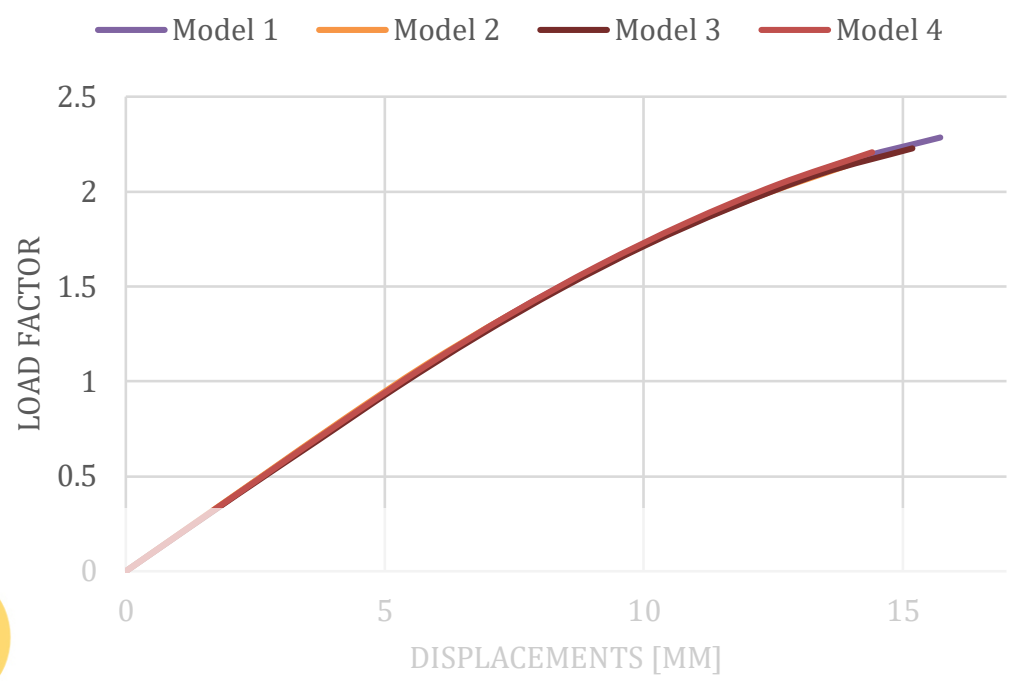

Figure 6: Capacity curve of the incremental vertical analysis
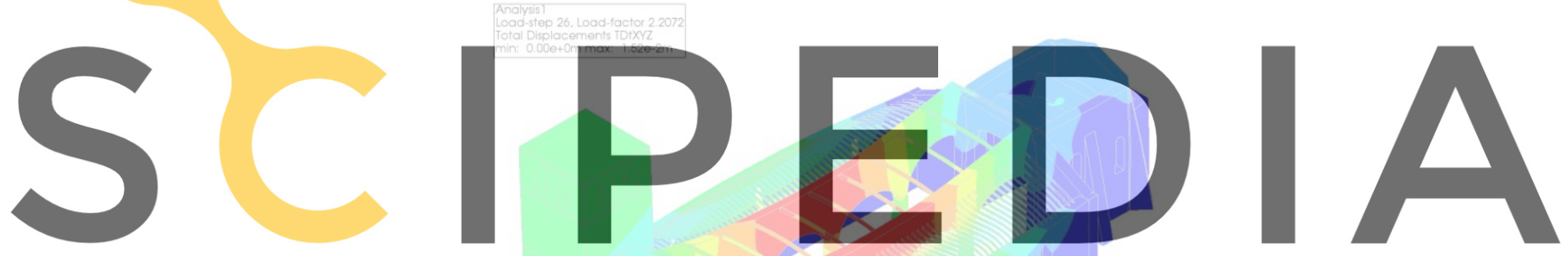

Register for free at https//www.scipedia.com to download the version without the watermark
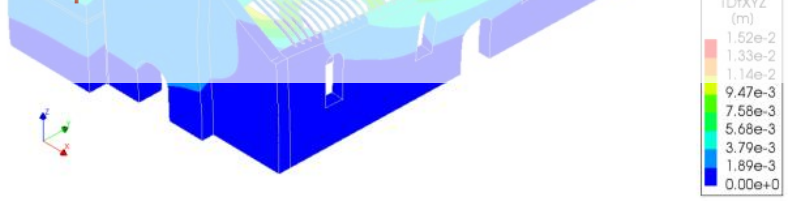

Figure 7: Displacements of the incremental vertical analysis

For the horizontal pushover both the transversal and longitudinal axes were analyzed in one direction. In the case of the transversal direction (X) the church presents a load factor around 0.17 and the capacity curve presents hardening. As expected, in the longitudinal direction (Y) the structure presents higher capacity and the curve reaches a value of 0.3 with an elastic behavior. The nonlinear branch presents softening in this case.

The strain graphs for the pushover in X shows concentrations in the base of the columns and in the connection of the arch of the choir with the lateral wall, see Figure 9. To a lesser extent, strain also appears in the base of the longitudinal walls. 

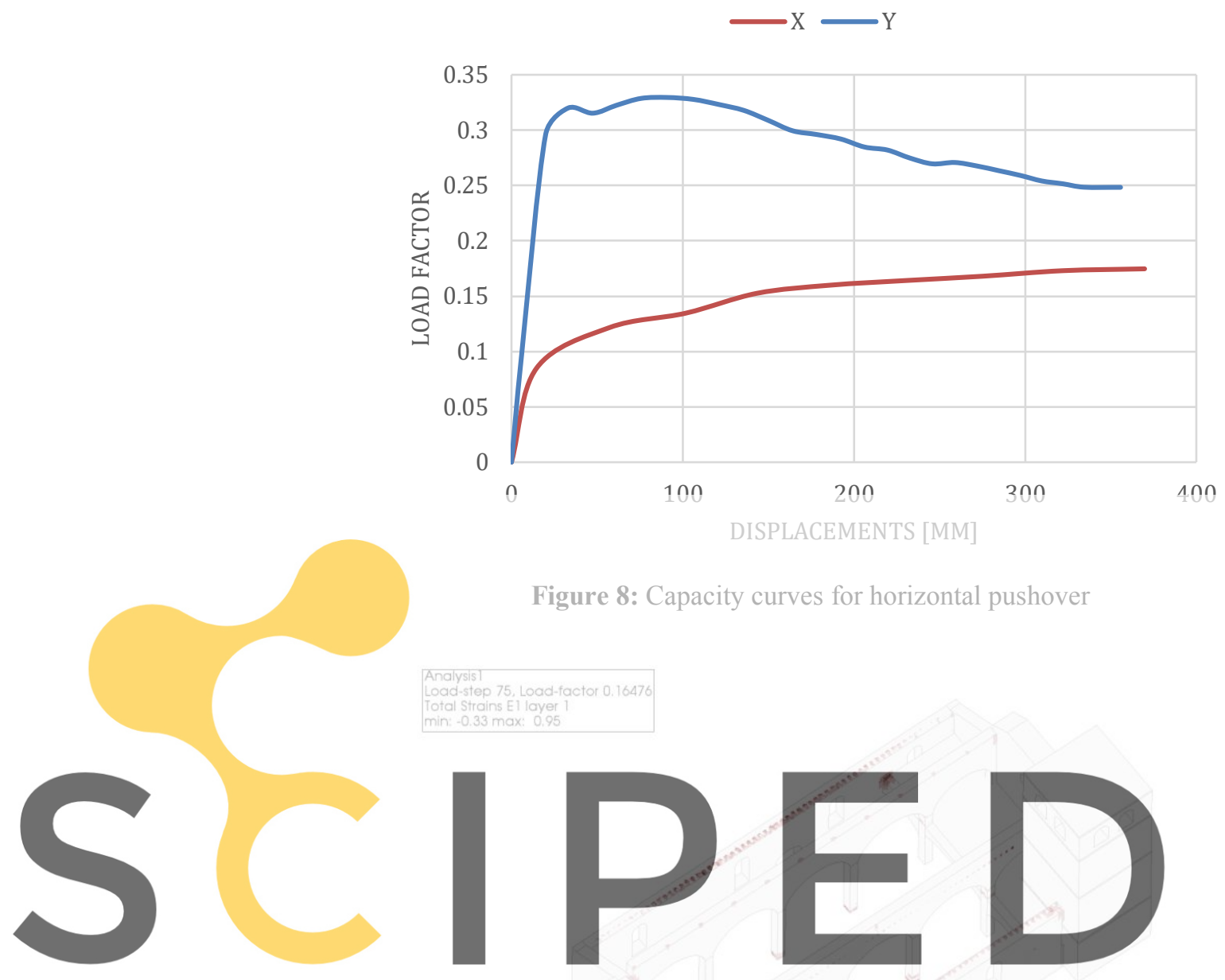

Figure 8: Capacity curves for horizontal pushover
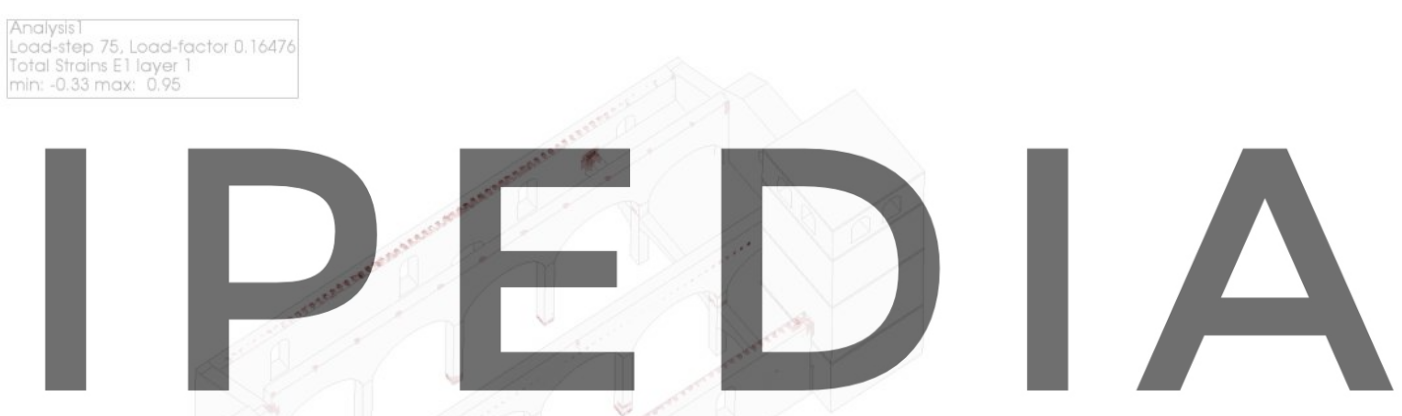

Register for free at https//www.scipedia.com to download the version without the watermark

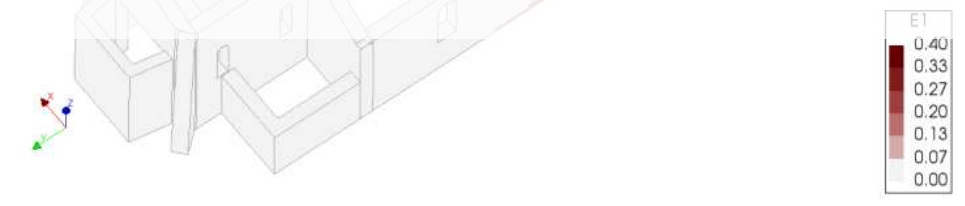

Figure 9: Maximum principal strains E1, x-direction

A different pattern is obtained from the pushover analysis in the y-direction. In this case the strain concentration is located at the base of the tower and the main façade in the shape of horizontal lines (Figure 10(a)), as well as in the connection of the tower with the church walls and in the body of the altar, where the strain pattern is diagonal in the lateral walls and vertical in the wall perpendicular to the force (Figure 10(b)). This diagonal concentration indicates shear failure may happen in the chancel under high loading in the y-direction. Maximum strain values are located in the connection of the arches of the choir with the longitudinal walls. 
Since northern Portugal has low earthquake risk (reference peak ground acceleration $0.08 \mathrm{~g}$, Portuguese National Annex to Eurocode 8 [11]), it can be concluded that the structure is not likely to surpass the linear range nor sustain much damage in any ground motion events.

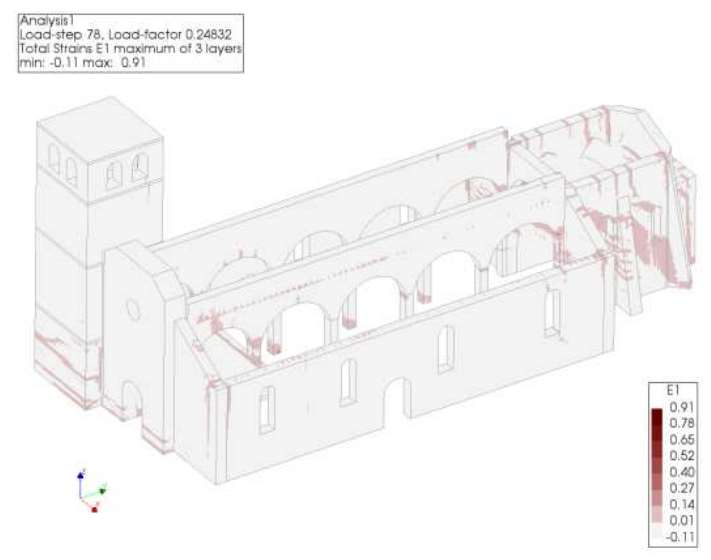

(a)

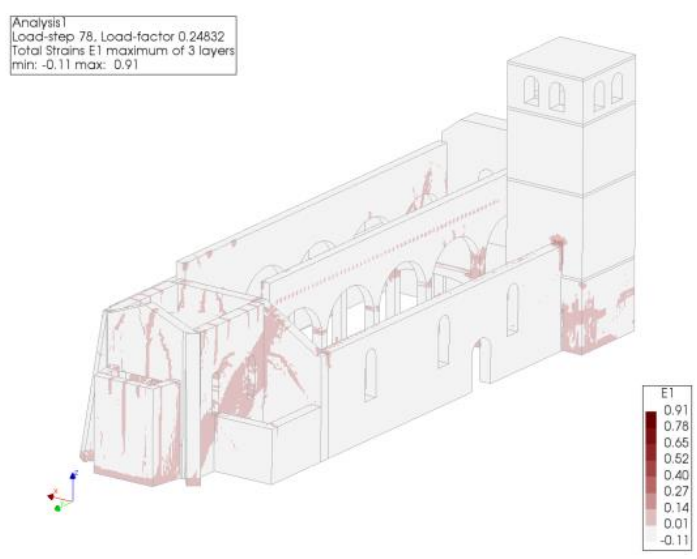

(b)

Figure 10: Maximum principal strains E1, y-direction (a) front view; (b) rear view

\section{CONCLUSION AND RECOMMENDATIONS}

The overall state of conservation of the church is good. No major structural deficiencies were observed. Recommendations include repointing in areas of lost mortar, cleaning of efflorescence and staining, replacing rotted wood, applying a chemical anti-termite barrier in walls and altars, improving ventilation, installing a stormwater drainage system, and performing continued monitoring and maintenance.

The non-destructive tests provided essential information about the conservation states of the materials and the multitude of tests allowed them to be verified against one another. The tests also supplied values of material properties for defining the finite element model.

Finite element analysis provided valuable information about the capacity of the church, both for self weight and horizontal load caused by an earthquake. The vertical loading case raised no concern for the current state of the church. The horizontal loading cases identified areas of possible weakness in case of earthquake, but it is noted that the church is unlikely to experience seriously threatening ground motions.

Acknowledgements. Direção Regional de Cultura do Norte, Dr. Miguel Rodrigues; Igreja de Azurara, Padre Diogo Oliveira, D. Zinha; Francisco and Guideline Geo; Sr. Matos and Structures lab of U. Minho; Nuno Mendes

\section{REFERENCES}

[1] I. Sereno, P. Noé, and P. Figueiredo, "Igreja de Azurara/Igreja de Santa Maria," Sistema de Informação para o Património Arquitectónico, 2012. [Online]. Available: http://www.monumentos.gov.pt/Site/APP_PagesUser/SIPA.aspx?id=5240.

[2] ICOMOS-ISCS. (2008). Illustrated glossary on stone deterioration patterns. ICOMOS. 
[3] IMIT (2009) Circ. 02.02.2009, n. 617: Istruzioni per l'applicazione delle Nuove Norme Tecniche per le Costruzioni di cui al decreto ministeriale 14 gennaio 2008. Italian Ministry of Infrastructures and Transportation, Rome, Italy (in Italian)

[4] Vasconcelos, Graça, et al. "Prediction of the Mechanical Properties of Granites by Ultrasonic Pulse Velocity and Schmidt Hammer Hardness." 10th North American Masonry Conference, 3-5 June 2007, no. January 2007, 2007, pp. 980-91.

[5] NTC. Norme Tecniche per le Costruzioni. D.M. 14 gennaio 2008, S.O. No. 30, G.U. No. 29/2008. Rome, Italy; 2008.

[6] The International Federation for Structural Concrete (fib). "Model Code 2010." Fib Model Code for Concrete Structures 2010, no. September, 2011, doi:10.1002/9783433604090.ch6.

[7] Kržan, Meta, et al. "Acquiring Reference Parameters of Masonry for the Structural Performance Analysis of Historical Buildings.” Bulletin of Earthquake Engineering, vol. 13, no. 1, 2015, pp. 203-36, doi:10.1007/s 10518-014-9686-x.

[8] Ortega, Javier, et al. "Assessment of the Efficiency of Traditional Earthquake Resistant Techniques for Vernacular Architecture.” Engineering Structures, vol. 173, no. June, Elsevier, 2018, pp. 1-27, doi:10.1016/j.engstruct.2018.06.101.

[9] EN 1996-1-1 (2005) Eurocode 6: Design of masonry structures - Part 1-1: General rules for buildings - rules for reinforced and unreinforced masonry.

[10]TNO DIANA BV.: DIANA User's Manual -- Release 9.3 -- 2008.

[11]A. Campos Costa, M. L. Sousa, and A. Carvalho, "Seismic Zonation for Portuguese National Annex of Eurocode 8," in The 14th World Conference on Earthquake Engineering, 2008. 